\title{
Techniques and productivity of coppice harvesting operations in Europe: a meta-analysis of available data
}

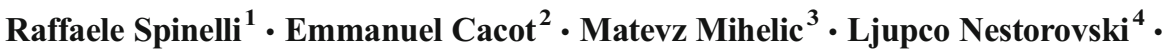 \\ Piotr Mederski ${ }^{5} \cdot$ Eduardo Tolosana $^{6}$
}

Received: 14 March 2016/Accepted: 10 August 2016 /Published online: 21 September 2016

(C) INRA and Springer-Verlag France 2016

\begin{abstract}
- Key message Coppice harvesting technology is evolving toward increased mechanization and larger more efficient equipment. Nevertheless, cheap and versatile general-
\end{abstract}

Handling Editor: Barry Alan Gardiner

Contribution of the co-authors All the authors worked at collecting the data and refining the data, writing the paper and discussing its results. Dr. Spinelli and Prof. Tolosana also worked at the statistical analysis of the data. The research project was coordinated by Dr. Spinelli

Raffaele Spinelli

spinelli@ivalsa.cnr.it

Emmanuel Cacot

Emmanuel.cacot@ fcba.fr

Matevz Mihelic

Matevz.Mihelic@bf.uni-lj.si

Ljupco Nestorovski

nestorovski@sf.ukim.edu.mk

Piotr Mederski

piotr.mederski@up.poznan.pl

Eduardo Tolosana

eduardo.tolosana@upm.es

1 CNR IVALSA, Via Madonna del Piano 10, Sesto Fiorentino, FI, Italy

2 FCBA, Les Vaseix, Verneuil-sur-Vienne, France

3 Department of Forestry and Renewable Resources, University of Ljubljana, Večna pot 83, Ljubljana, Slovenia

4 Ss. Cyril and Methodius University of Skopje, Bul. Aleksandar Makedonski, Skopje, Macedonia

5 Faculty of Forestry, Poznań University of Life Sciences, Wojska Polskiego $71^{\circ}$, Poznań, Poland

6 Universidad Politécnica de Madrid, Ciudad Universitaria s/n, Madrid, Spain purpose machines (excavators and farm tractors) still represent the backbone of coppice mechanization, which is consistent with the rural character of coppice economy.

- Context Operating within the scope of COST Action FP1301 "Eurocoppice", the authors conducted a survey of coppice harvesting studies produced in Europe from 1970 to present. The survey focused on traditional coppice stands and excluded industrial short-rotation coppice, established with willow, poplar, eucalyptus, or other fast-growing species.

- Aims The goals of this study were to calculate productivity benchmarks for coppice harvesting operations and to gauge the progress achieved over the past 40-plus years.

- Methods Data from existing studies (published and unpublished) were collected through a harmonized questionnaire and gathered into a single master database. Statistical analysis was used to estimate productivity models and determine possible differences between methods, work conditions, and time periods.

- Results Six productivity models were estimated for the main harvesting steps and technologies. Productivity varied with a number of factors and notably with removal $\left(\mathrm{m}^{3} \mathrm{ha}^{-1}\right)$. The analysis disclosed a clear trend toward increased mechanization and higher productivity.

- Conclusion Coppice harvesting is being mechanized, but the mechanization deployed in coppice stands is adapted to the specific conditions offered by these stands. Light, cheap, and versatile machines are generally preferred to heavy industrial equipment.

Keywords Felling $\cdot$ Extraction $\cdot$ Logging $\cdot$ Hardwood mechanization $\cdot$ Clear cut $\cdot$ Selection

\section{Introduction}

Long and intense settlement history makes human activity a characterizing factor of European forestry (Szabò 2009). In 
Europe, old growth is relegated to a few remote areas, which have remained inaccessible (Splechtna et al. 2005). Most European forests are under active management or have been under active management until recent years (Kirby and Watkins 1998). Near rural settlements, coppice stands are often abundant because they are well suited to provide for the immediate material needs of a dense rural population (Wolfslehner et al. 2009). For centuries, these forests have provided local communities with firewood, posts, tool handles, and fencing materials (Buckley 1992). Coppice stands are economically efficient, due to the short waiting time (1530 year rotations) and simplified management (clear-cut at the end of rotation and regeneration by resprouting). Coppice management was popular all over Europe in the recent past, and today it is still widespread in the Mediterranean and Balkan regions (Jansen and Kuiper 2004), and in general, wherever industrialization was not introduced so early as to shape all the landscape, including forestry (Spinelli et al. 2014). In Europe, coppice is especially common in France (6.3 million ha), Italy (3.3 million ha), Bulgaria (1.8 million ha), Greece (1.7 million ha), and Serbia and Montenegro (1.4 million ha). Bosnia-Herzegovina, Croatia, Macedonia, and Hungary represent between 0.5 and 1 million hectares of coppice each. Coppice accounts for much smaller areas in the other European countries, but it is present in all of them, at least to some extent (Nicolescu et al. 2014).

However, the European coppice economy is suffering due to the competition from oil and plastic (Hédl et al. 2010), and especially from the reduced availability of rural labor, willing to accept heavy and low-paying jobs. Under these conditions, frequent harvesting has turned from an advantage into a drawback, and delayed cutting of aged coppice has become increasingly common.

Fortunately, there is still a strong interest in restoring and maintaining traditional coppice stands, which may play a crucial role in supporting rural development, while providing a wealth of new products and services, especially soil protection, biodiversity, energy biomass, and carbon sequestration (Vacik et al. 2009).

For this reason, it is important to improve the efficiency of coppice harvesting operations, facilitating the transition of coppice management from a part-time rural activity to a modern industrial business. Mechanization may seem the obvious solution, but the simple extension of modern technology to coppice management is no guarantee of immediate success. Coppice stands present some features that may not suit conventional forest technology. Steep terrain and small stem size represent severe constraints, which are encountered in most coppice stands (Magagnotti et al. 2012). What is more, coppice presents the peculiar characteristic of sprouting multiple stems from the same stump. That is especially challenging when trying to introduce mechanized felling to coppice harvesting operations, because stem crowding hinders felling head movements and can be handled by very compact units only (Spinelli et al. 2010). A further constraint of coppice harvesting operations is the absolute need to prevent stump damage, in order to guarantee prompt regeneration. All cuts must be clean and as near to the ground as possible. For the same reason, extraction machines must not climb on stumps, and the use of tracks and tire chains is often discouraged in coppice operations.

Increasing the efficiency of coppice harvesting requires a good understanding of current operations, regardless of technology level. In fact, a wide-ranging survey may help to pinpoint problem areas and possible solutions. Much research has already been conducted about coppice harvesting, but the majority of these studies have not achieved international visibility, partly due to their local character and partly to the limited interest into coppice-related subjects.

Therefore, the goals of this study were (1) to gather previous coppice harvesting studies into a large harmonized database, (2) to determine the regional importance of the subject, (3) to produce benchmark productivity figures and functions, and (4) to gauge the change in technology and performance over time.

\section{Materials and methods}

The study was performed within the scope of COST Action FP1301, which endeavored to show the state-of-the-art of coppice research in Europe. The authors took up the task of covering coppice harvesting research and enrolled the support of national delegates appointed to represent 30 countries. The authors first developed a harmonized query format, and then asked national delegates to provide a list of scientific publications produced within their respective countries on the topic of coppice harvesting from 1970 to present. Accepted source material included national and international journal articles, project reports (published and internal), and theses. When a paper was in a national language that none of the authors could understand, then the national delegates were asked to fill out themselves the query forms, in order to minimize translation errors. The basic query format requested inputs about (1) country of origin and reference title; (2) site and stand characteristics; (3) work technique, equipment, crew size, net productivity, and delay incidence - separately for each work phase, i.e. felling, processing, and extraction.

Overall, 102 forms were collected. Data from each individual form were consolidated into one large master database, containing separate worksheets for each work phase. This yielded a total of 377 data points, variously distributed among countries and work phases (Table 1). Data were analyzed statistically using the Statview software (SAS Institute Inc 1999). As a first step, descriptive statistics were drawn, separately for each work phase. Then, the significance of the differences 
Table 1 Data points by country of origin and work phase

\begin{tabular}{lllll}
\hline Country & \multicolumn{2}{l}{ Work phase } & \\
\cline { 2 - 5 } & Felling & Processing & Harvesting & Extraction \\
\hline France & 3 & 3 & 52 & 3 \\
Germany & 0 & 0 & 1 & 0 \\
Italy & 49 & 43 & 35 & 115 \\
Poland & 0 & 0 & 4 & 0 \\
Serbia & 4 & 0 & 0 & 2 \\
Slovenia & 2 & 0 & 0 & 2 \\
Spain & 4 & 6 & 12 & 22 \\
UK & 3 & 3 & 4 & 5 \\
Total & 65 & 55 & 108 & 149 \\
\hline
\end{tabular}

between mean values for different options was tested with non-parametric techniques, in order to overcome any violations of the statistical assumptions. The significance of any differences between distributions was checked using a classic $\chi^{2}$ test. Linear and non-linear regression analysis of the data allowed testing of the relationship between productivity and the main site, stand, and technical work conditions, for each work phase. Regressions were assumed as the productivity benchmark of each specific work system and technology, as deployed in coppice harvesting. The regression coefficient $R^{2}$ was taken as an indicator of how strong the effect of the main site and technical parameters on productivity was. The mean absolute error (MAE) was used to compare alternative regression models, in order to select the most reliable ones (Chai and Draxler 2014).

For the sake of simplification, the analysis was divided into three parts: the first part dealing with the database in general; the second part dealing with "felling," "processing," and combined "felling-processing" (henceforth called "harvesting"); and the third part dealing with extraction. Grouped work steps (i.e., felling, processing, and harvesting) presented important similarities and generally reacted to the same independent variables, which explained aggregation. On the other hand, the two groups of felling and extraction included inherently different activities that reacted to different independent variables, which justified separate analysis.

\section{Results}

\subsection{Characteristics of the database}

The search was conducted within the scope of COST Action FP1301 and covered 14 countries, where part of the forest resource is traditionally managed as coppice. The search focused on traditional coppice and excluded new high-density short-rotation coppice plantations grown for energy, generally established with willows, poplars, and robinia. These stands are established on ex-arable land at densities exceeding 6000 stools ha ${ }^{-1}$, (ca. three times higher than traditional coppice), and they are clear-cut at 2- to 5-year intervals (ca. five to ten times shorter than for traditional coppice). For this reason, short-rotation coppice is generally considered an agricultural crop rather than a forest crop. The study also excluded industrial eucalypt plantations, even if they are often managed as coppice (McEwan et al. 2016). Eucalypt plantations are very different from traditional coppice stands in terms of management, economics, ecology, and cultural value (Siry et al. 2005). Stands included in the database consisted of beech, chestnut, oaks, and other indigenous species. The database occasionally included naturalized exotics (typically robinia), if these were grown according to traditional practice.

Viable coppice studies were sourced from eight countries only. In the other countries, no studies were found that dealt directly with the harvesting of traditional coppice forests. The largest majority of the studies were found in France and Italy, together accounting for $84 \%$ of the studies (Fig. 1) and $80 \%$ of the single data points (Table 1). In fact, more than one data point was obtained from a study if the study covered different work phases or different technological options.

Of the 102 studies used to build the database, only $20 \%$ had been published in English. In fact, over $50 \%$ of the studies collected in this survey consisted of unpublished internal reports, which were not available to the larger scientific community. The remaining $30 \%$ of the studies had been published in national languages different from English and were difficult to access for most researchers.

\subsection{Felling, processing, and "harvesting"}

First of all, it is useful to define the work phases considered here. Felling consists of cutting the tree at the base and laying it down without any further processing. In contrast, processing is defined as removing the limbs from pre felled stems and crosscutting the stems into commercial lengths. Finally, harvesting is the uninterrupted sequence of felling and processing. Felling, processing, and harvesting can be performed manually with a chainsaw or mechanically with a feller, a processor, or a harvester.

Studies about mechanized operations were more recent than those conducted on manual operations, but the difference was statistically significant for harvesting only (Table 2).

Concerning work conditions, mechanized felling and mechanized harvesting were tested on flatter terrain than were their manual counterparts, while no terrain differences were found between manual and mechanized processing. Mechanized operations did not target larger removals or specific treatments (i.e., clear cut or conversion to high forest) compared with manual operations, except for mechanized 
Fig. 1 Number of studies by country of origin and document type

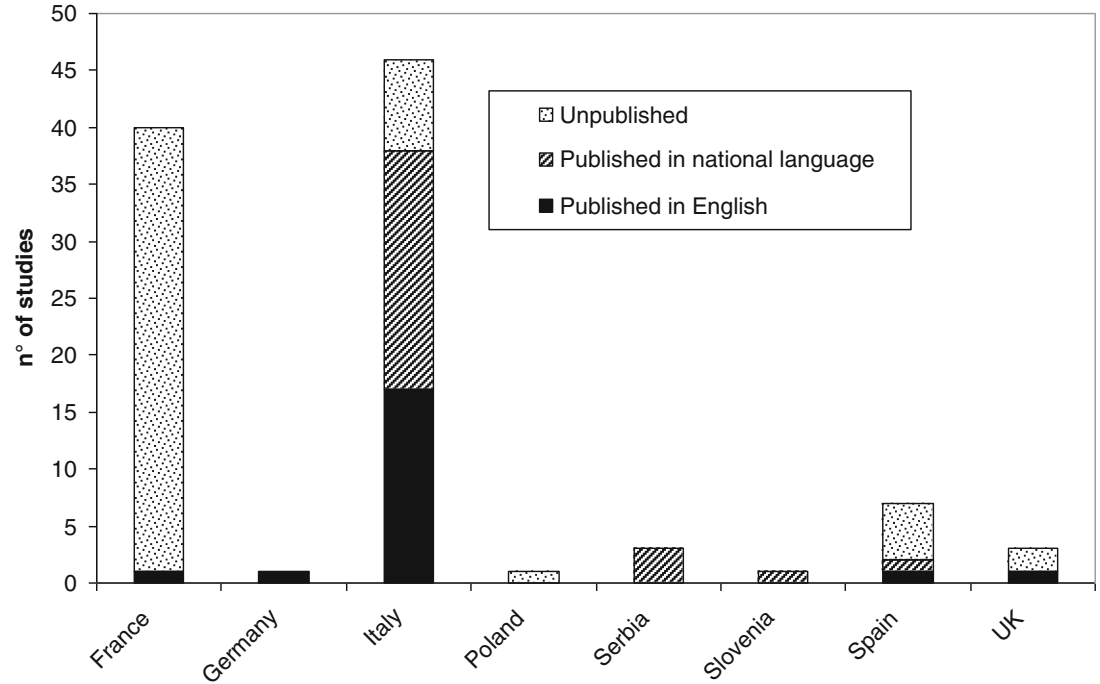

processing that was deployed preferentially on clear cuts, with large removals. Mechanized processing and mechanized harvesting were systematically deployed on larger trees than were manual processing and manual harvesting, whereas no tree size differences were found for felling. In fact, data were suggestive of mechanized felling being associated with smaller tree size compared with manual felling, although this difference lacked statistical significance $(P=0.166)$. Mechanized processing and mechanized harvesting studies were most often associated with chestnut coppice, whereas their manual counterparts related preferentially to oaks. Oaks were also the most frequent species considered in mechanized felling studies, whereas manual felling studies showed a more even spread. This likely depended on the fact that mechanized
Table 2 Main results of the analysis of felling, processing, and harvesting data

\begin{tabular}{|c|c|c|c|c|c|c|}
\hline \multirow{2}{*}{$\begin{array}{l}\text { Work phase } \\
\text { Technology level } \\
\text { Date study (year) }\end{array}$} & \multicolumn{2}{|l|}{ Felling } & \multicolumn{2}{|c|}{ Processing } & \multicolumn{2}{|c|}{ Harvesting } \\
\hline & $\begin{array}{l}\text { Manual } \\
\text { 2003a }\end{array}$ & $\begin{array}{l}\text { Mech. } \\
2008 \mathrm{a}\end{array}$ & $\begin{array}{l}\text { Manual } \\
\text { 2005a }\end{array}$ & $\begin{array}{l}\text { Mech. } \\
\text { 2008a }\end{array}$ & $\begin{array}{l}\text { Manual } \\
\text { 1998a }\end{array}$ & $\begin{array}{l}\text { Mech. } \\
2008 b\end{array}$ \\
\hline \multicolumn{7}{|l|}{ Site characteristics } \\
\hline Slope gradient $(\%)$ & $36 \mathrm{a}$ & $10 \mathrm{~b}$ & $31 \mathrm{a}$ & $33 \mathrm{a}$ & $21 \mathrm{a}$ & $9 \mathrm{~b}$ \\
\hline Clear cut $(n)$ & $21 \mathrm{a}$ & $6 a$ & $4 a$ & $16 b$ & $46 \mathrm{a}$ & $22 \mathrm{a}$ \\
\hline Conversion $(n)$ & $23 \mathrm{a}$ & $11 \mathrm{a}$ & $16 \mathrm{a}$ & $6 \mathrm{~b}$ & $25 \mathrm{a}$ & $12 \mathrm{a}$ \\
\hline Total removal $\left(\mathrm{m} 3 \mathrm{ha}^{-1}\right)$ & $116 \mathrm{a}$ & $118 \mathrm{a}$ & $88 \mathrm{a}$ & $162 \mathrm{~b}$ & $149 \mathrm{a}$ & $172 \mathrm{a}$ \\
\hline Tree size $\left(\mathrm{m}^{3}\right)$ & $0.19 \mathrm{a}$ & $0.121 \mathrm{a}$ & $0.134 \mathrm{a}$ & $0.164 b$ & $0.116 \mathrm{a}$ & $0.148 b$ \\
\hline \multicolumn{7}{|l|}{ Tree species } \\
\hline Chestnut (\%) & 30 & 18 & 24 & 55 & 30 & 48 \\
\hline Beech $(\%)$ & 26 & 0 & 24 & 18 & 8 & 0 \\
\hline Oaks (\%) & 30 & 53 & 52 & 9 & 61 & 44 \\
\hline Other $(\%)$ & 14 & 29 & 0 & 18 & 1 & 8 \\
\hline Distribution $\left(\chi^{2}\right)$ & 8.374 & $(P=0.039)$ & 14.334 & $(P=0.002)$ & 9.326 & $(P=0.025)$ \\
\hline \multicolumn{7}{|l|}{ Operation } \\
\hline Crew $\left(n^{\circ}\right)$ & $1.6 \mathrm{a}$ & $1 b$ & $1.8 \mathrm{a}$ & $1 \mathrm{~b}$ & $1.6 \mathrm{a}$ & $1 b$ \\
\hline Utilization (\%) & $66 a$ & $80 \mathrm{~b}$ & $68 \mathrm{a}$ & $77 \mathrm{~b}$ & $64 \mathrm{a}$ & $76 \mathrm{~b}$ \\
\hline $\begin{array}{l}\text { Productivity }\left(\mathrm{m}^{3} \mathrm{~h}^{-1}\right. \\
\left.\text { worker }^{-1}\right)\end{array}$ & $3.3 \mathrm{a}$ & $6.9 \mathrm{~b}$ & $1.0 \mathrm{a}$ & $7.0 \mathrm{~b}$ & $1.3 \mathrm{a}$ & $6.5 \mathrm{~b}$ \\
\hline $\mathrm{n}$ sorts $(n)$ & - & - & $1.7 \mathrm{a}$ & $2.4 \mathrm{a}$ & $1.3 \mathrm{a}$ & $2.5 \mathrm{~b}$ \\
\hline Min log length (m) & - & - & $1.5 \mathrm{a}$ & $2.4 \mathrm{~b}$ & $2.1 \mathrm{a}$ & $2.3 \mathrm{a}$ \\
\hline Max log length (m) & - & - & $2.7 \mathrm{a}$ & $4.3 b$ & $2.9 \mathrm{a}$ & $3.7 b$ \\
\hline
\end{tabular}

Different letters for the technology levels (i.e., manual vs. mechanized) of the same work phase indicate a statistically significant difference for $\alpha<0.05$; the significance of the differences found in the species distribution is indicated in the $\chi^{2}$ row; utilization $=$ productive work time/worksite time 
technology deployed in oak stands was generally designed for the production of whole-tree chips, and therefore it did not integrate any delimbing and crosscutting (i.e., processing) capabilities.

Compared with manual operations, mechanized operations were characterized by a smaller crew size, a higher utilization, and a much higher worker productivity (two to seven times). Mechanized processing and mechanized harvesting tended to produce more log specifications than did their manual counterparts, although this difference was significant for harvesting only. However, maximum log length was significantly higher for mechanized operations, compared with manual ones (Table 2).

Regression analysis showed that worker productivity was strongly affected by technology level and by stem size or total removal (Table 3). Stem size had a marked effect on productivity in single-stem operations, namely, processing and harvesting. In contrast, felling productivity reacted better to total removal than to stem size (Fig. 2).

\subsection{Extraction}

"Extraction" is defined as the moving of cut trees or processed logs from the stump site to a roadside landing or a landing pad, accessible to transport vehicles.

The database contained 142 valid data points, which were attributed to one of the following extraction systems: animal extraction, sliding in chutes, shoveling (i.e., moving to the landing with an excavator), skidding (dragging on the ground behind a tractor), forwarding (carrying on a loading deck), and cable yarding. However, animal extraction, sliding in chutes, and shoveling were represented by relatively few data points, and inference for these specific extraction methods could not be as solid as for the other methods. In that regard, it is important to consider that animal extraction was performed exclusively with mules and horses, which hauled short logs on packsaddles in seven cases out of eight (the remaining one consisting of horse skidding). On the same note, skidding and forwarding were performed with forestry-fitted farm tractors in 85 and $60 \%$ of the cases, respectively. Concerning the direction of extraction, sliding occurred exclusively (and obviously) downhill; animal logging, skidding, and forwarding occurred preferably downhill, but occasionally also uphill; yarding occurred uphill in three cases out of four.

Studies about animal logging, sliding in chutes, and skidding were generally older than studies about shoveling, forwarding, and yarding, indicating a shift of interest toward more modern systems, which may or may not depend on the growing popularity of these more mechanized systems among logging contractors engaged with coppice operations (Table 4).

Concerning work conditions, mechanized ground-based systems (i.e., skidding and forwarding) were generally associated with lower slope gradients than were cable-systems and non-mechanized ground-based systems (i.e., animals and sliding). In contrast, the analysis did not disclose any significant relationships between extraction system and silvicultural practice (i.e., clear cut or conversion to high forest), removal, or
Table 3 Regression equations for felling, processing, and harvesting productivity

\begin{tabular}{|c|c|c|c|c|}
\hline \multicolumn{5}{|c|}{ Felling } \\
\hline \multicolumn{5}{|c|}{$\mathrm{m}^{3} \mathrm{~h}^{-1}$ worker $^{-1}=\mathrm{a}^{*}$ Removal $+\mathrm{b} *$ Removal $*$ Mech } \\
\hline \multicolumn{5}{|c|}{$R^{2}$ adjusted $=0.764, n=60$} \\
\hline & Coefficient & SE & F-value & $P$ value \\
\hline a & 0.029 & 0.003 & 8.790 & $<0.0001$ \\
\hline $\mathrm{b}$ & 0.027 & 0.006 & 4.477 & $<0.0001$ \\
\hline \multicolumn{5}{|c|}{ Processing } \\
\hline \multicolumn{5}{|c|}{$\mathrm{m}^{3} \mathrm{~h}^{-1}$ worker $^{-1}=\mathrm{a}^{*}$ Stem size $+\mathrm{b} *$ Stem size*Mech } \\
\hline \multicolumn{5}{|c|}{$R^{2}$ adjusted $=0.844, n=38$} \\
\hline & Coefficient & SE & F-value & $P$ value \\
\hline a & 11.243 & 5.304 & 2.120 & 0.0410 \\
\hline $\mathrm{b}$ & 32.283 & 6.121 & 5.274 & $<0.0001$ \\
\hline \multicolumn{5}{|c|}{ Harvesting } \\
\hline \multicolumn{5}{|c|}{$\mathrm{m}^{3} \mathrm{~h}^{-1}$ worker $^{-1}=\mathrm{a}+\mathrm{b} *$ Stem size $+\mathrm{c} *$ Mech $+\mathrm{d}^{*}$ Stem size*Mech } \\
\hline \multicolumn{5}{|c|}{$R^{2}$ adjusted $=0.773, n=107$} \\
\hline & Coefficient & SE & F-value & $P$ value \\
\hline a & 0.645 & 0.238 & 2.704 & 0.0080 \\
\hline $\mathrm{b}$ & 5.430 & 1.259 & 4.311 & $<0.0001$ \\
\hline $\mathrm{c}$ & 2.504 & 0.52 & 4.817 & $<0.0001$ \\
\hline $\mathrm{d}$ & 16.948 & 2.842 & 5.964 & $<0.0001$ \\
\hline
\end{tabular}

Mech $=0$ if operation is manual, Mech = 1 if operation is mechanized

$S E$ standard error, Removal total removal in $\mathrm{m}^{3} \mathrm{ha}^{-1}$, Stem size mean stem volume in $\mathrm{m}^{3}$ 
Fig. 2 Felling productivity as a function of removal and technology level

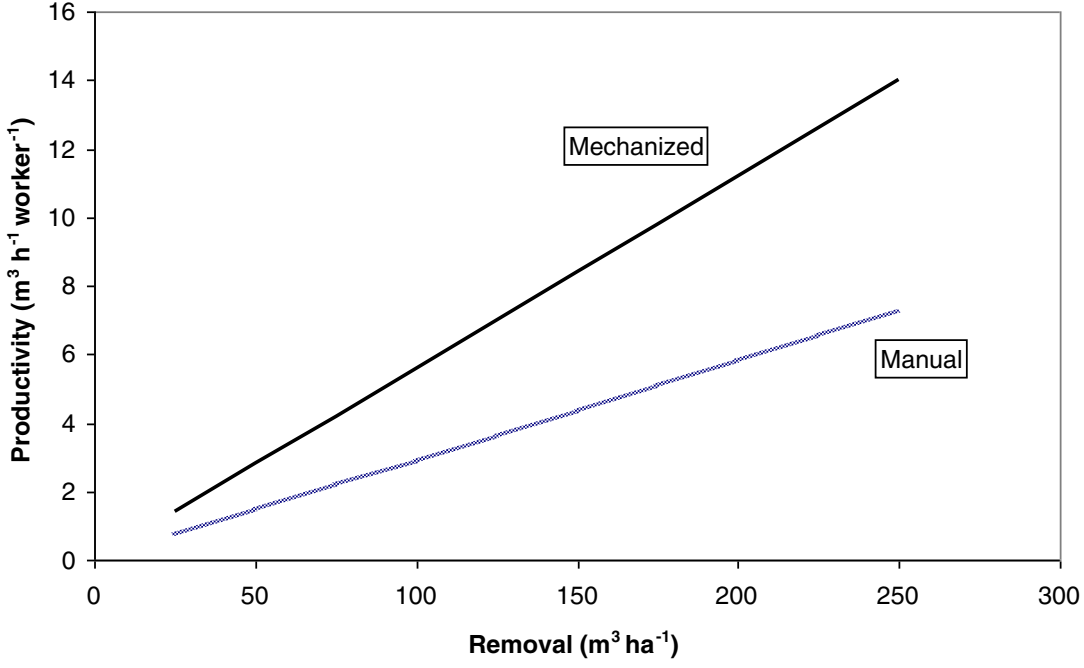

stem size. On the other hand, the classic $\chi^{2}$ showed that yarding was more frequent in beech stands, while skidding and forwarding were more frequent in oak stands (Table 2).

Except for shoveling, crew size was always relatively large, which was consistent with substantial labor input, as required for the manual loading of mules, forwarding boxes, and trailers or for the manual choking of skidder and yarder loads.
Labor inputs were significantly larger for log sliding, which is an almost entirely manual practice. This could also explain the significantly lower utilization recorded for this method, which is physically demanding. Different extraction distance and mean load size were also associated with different systems, as befitted their specific technical characteristics. In particular, forwarding was associated with the largest loads and the
Table 4 Main results of the analysis of "extraction" data

\begin{tabular}{|c|c|c|c|c|c|c|}
\hline $\begin{array}{l}\text { System } \\
n \\
\text { Date (year) }\end{array}$ & $\begin{array}{l}\text { Animal } \\
8 \\
1996 a\end{array}$ & $\begin{array}{l}\text { Chutes } \\
5 \\
1996 a\end{array}$ & $\begin{array}{l}\text { Shovel } \\
3 \\
2006\end{array}$ & $\begin{array}{l}\text { Skidding } \\
52 \\
2000 \mathrm{a}\end{array}$ & $\begin{array}{l}\text { Forwarding } \\
41 \\
2005 b\end{array}$ & $\begin{array}{l}\text { Yarding } \\
33 \\
2006 \mathrm{~b}\end{array}$ \\
\hline \multicolumn{7}{|l|}{ Site characteristics } \\
\hline Slope gradient (\%) & $48 \mathrm{a}$ & $49 \mathrm{a}$ & 35 & $30 \mathrm{~b}$ & $22 b$ & $57 \mathrm{a}$ \\
\hline Clear cut $(n)$ & 7 & 2 & 3 & 31 & 16 & 15 \\
\hline Conversion $(n)$ & 1 & 3 & 0 & 22 & 25 & 17 \\
\hline Total removal $\left(\mathrm{m}^{3} \mathrm{ha}^{-1}\right)$ & $121 \mathrm{a}$ & $119 \mathrm{a}$ & 213 & $108 \mathrm{a}$ & $92 \mathrm{a}$ & $118 \mathrm{a}$ \\
\hline Tree size $\left(\mathrm{m}^{3}\right)$ & $0.102 \mathrm{a}$ & $0.126 \mathrm{a}$ & 0.417 & $0.109 \mathrm{a}$ & $0.158 \mathrm{a}$ & $0.161 \mathrm{a}$ \\
\hline \multicolumn{7}{|l|}{ Tree species } \\
\hline Chestnut (\%) & 25 & 20 & 67 & 23 & 17 & 12 \\
\hline $\operatorname{Beech}(\%)$ & 0 & 40 & 0 & 13 & 5 & 48 \\
\hline Oaks (\%) & 75 & 40 & 0 & 47 & 78 & 36 \\
\hline Other $(\%)$ & 0 & 0 & 33 & 17 & 0 & 3 \\
\hline Distribution $\left(\chi^{2}\right)$ & \multicolumn{6}{|c|}{$388.814(P=<0.0001)$} \\
\hline \multicolumn{7}{|l|}{ Operation } \\
\hline Crew $(n)$ & $1.9 \mathrm{a}$ & $3.2 b$ & 1.0 & $1.9 \mathrm{a}$ & $1.5 \mathrm{a}$ & $2.6 \mathrm{~b}$ \\
\hline Utilization (\%) & $91 \mathrm{a}$ & $65 b$ & 80 & $78 \mathrm{a}$ & $83 a$ & $77 \mathrm{a}$ \\
\hline Distance $(\mathrm{m})$ & $396 \mathrm{ac}$ & $96 b$ & 158 & $294 a$ & $750 \mathrm{c}$ & $236 \mathrm{a}$ \\
\hline Load per turn $\left(\mathrm{m}^{3}\right)$ & $1.112 \mathrm{a}$ & $0.014 \mathrm{a}$ & 0.299 & $0.843 \mathrm{a}$ & $5.219 b$ & $0.502 \mathrm{a}$ \\
\hline Productivity $\left(\mathrm{m}^{3} \mathrm{~h}^{-1}\right)$ & $1.8 \mathrm{a}$ & $2.4 \mathrm{a}$ & 8.7 & $2.9 \mathrm{a}$ & $6.0 \mathrm{~b}$ & $3.1 \mathrm{a}$ \\
\hline
\end{tabular}

Different letters along the same rows indicate a statistically significant difference between extraction systems for $\alpha<0.05$. Shovel extraction figures bear no letters because they were excluded from the analyses due to the insufficient number of data points. The significance of the differences found in the species distribution is indicated in the $\chi^{2}$ row. Utilization = productive work time/worksite time. Distance is the maximum extraction distance reported in the study (i.e., system reach). Load size in animal extraction refers to the total load hauled by the whole animal team, not by the single animal. Productivity figures refer to the whole extraction team and not to the single worker 
longest extraction distances, whereas sliding accounted for the smallest loads and the shortest distances. Productivity was significantly higher for shoveling and forwarding, compared with the other systems (Table 4).

Animal extraction, sliding, and shoveling did not offer enough data points for attempting individual regression analyses, whereas skidding, forwarding, and yarding did. The general model formulation was logical, since productivity increased with load size and decreased with distance, and the two independent variables tended to balance each other (Table 5). Removal had a significant effect on skidding and yarding, but not on forwarding. Other independent variables were also tested, but the data pool was not large enough for detecting any significant effects.

The use of these models is shown in Fig. 3, where forwarding productivity was modeled as a function of extraction distance and load size. In this specific example, the three load sizes represented three different forwarding equipment: a farm tractor with front and rear boxes $\left(2 \mathrm{~m}^{3}\right)$, especially popular with Mediterranean contractors; a farm tractor with a dedicated forestry trailer $\left(6 \mathrm{~m}^{3}\right)$; and a proper light- to medium-sized forwarder $\left(10 \mathrm{~m}^{3}\right)$.

Finally, the data for skidding, forwarding, and yarding were categorized in two groups, depending on whether they came

Table 5 Regression equations for skidding, forwarding, and yarding

\begin{tabular}{|c|c|c|c|c|}
\hline \multicolumn{5}{|c|}{$\begin{array}{l}\text { Skidding } \\
\qquad \mathrm{m}^{3} \mathrm{~h}^{-1}=\mathrm{a}^{*} \operatorname{Load}^{\wedge} \mathrm{b}^{*} \operatorname{Dist}^{\wedge} \mathrm{c}+\mathrm{d}^{*} \text { Removal } \\
R^{2} \text { adj }=0.839, n=48\end{array}$} \\
\hline & Coeff & $\mathrm{SE}$ & F-value & $P$ value \\
\hline a & 51.305 & 8.226 & 6.237 & $<0.0001$ \\
\hline $\mathrm{b}$ & 1.142 & 0.112 & 4.362 & $<0.0001$ \\
\hline $\mathrm{c}$ & -0.574 & 0.118 & -2.201 & 0.0023 \\
\hline$d$ & 0.009 & 0.002 & 3.83 & $<0.0001$ \\
\hline \multicolumn{5}{|c|}{ Forwarding } \\
\hline \multicolumn{5}{|c|}{$\mathrm{m}^{3} \mathrm{~h}^{-1}=\mathrm{a}^{*} \operatorname{Load}^{\wedge} \mathrm{b}^{*} \operatorname{Dist}^{\wedge} \mathrm{c}$} \\
\hline \multicolumn{5}{|c|}{$R^{2}$ adj $=0.894, n=31$} \\
\hline & Coeff & SE & F-value & $P$ value \\
\hline a & 55.369 & 1406.24 & 262.432 & $<0.0001$ \\
\hline $\mathrm{b}$ & 0.750 & 0.152 & 4.934 & $<0.0001$ \\
\hline $\mathrm{c}$ & -0.568 & 0.127 & -4.476 & $<0.0001$ \\
\hline \multicolumn{5}{|c|}{ Yarding } \\
\hline \multicolumn{5}{|c|}{$\mathrm{m}^{3} \mathrm{~h}^{-1}=\mathrm{a}^{*} \operatorname{Load}^{\wedge} \mathrm{b}^{*} \operatorname{Dist}^{\wedge} \mathrm{c}+\mathrm{d}^{*}$ Removal } \\
\hline \multicolumn{5}{|c|}{$R^{2}$ adj $=0.914, n=30$} \\
\hline & Coeff & $\mathrm{SE}$ & F-value & $P$ value \\
\hline $\mathrm{a}$ & 16.351 & 3.557 & 4.597 & $<0.0001$ \\
\hline b & 0.699 & 0.127 & 5.298 & $<0.0001$ \\
\hline $\mathrm{c}$ & -0.304 & 0.205 & -2.115 & 0.0031 \\
\hline d & 0.011 & 0.003 & 3.341 & 0.0024 \\
\hline
\end{tabular}

SE Standard error, Removal total removal in $\mathrm{m}^{3} \mathrm{ha}^{-1}$, Load mean load per turn in $\mathrm{m}^{3}$, Dist maximum extraction distance, in $\mathrm{m}$ from studies dated between 2006 and 2015 or from earlier studies (cf. Cacot et al. 2015a). The purpose of the exercise was to determine if any significant progress had occurred in coppice extraction performance. Data analysis confirmed that this was the case. The mean productivity reported in studies performed after 2005 was substantially higher than the mean productivity derived from earlier studies for all the three extraction systems, and the differences were statistically significant for skidding and forwarding (Table 6). However, productivity gains were obtained in different ways for the different systems. Increases in skidding productivity were associated with larger removals, hinting at a new deployment strategy rather than a technology change. In contrast, increases in forwarding and yarding productivity were associated with larger payloads and longer distances, which indicate the introduction of larger specialist machines.

\section{Discussion}

\subsection{General}

This study is a first attempt at conducting a large review and a meta-analysis of existing coppice harvesting studies, which would have been impossible without the large network of scientists supported by the European Union through COST Action 1301. Such a network has allowed access to the $80 \%$ of the studies that are not published in English. In fact, many of those studies have not been published at all and exist only as internal reports, personally contributed to this project by researchers participating in the network. For this reason, the scientific quality of many studies included in the analysis had not been verified by international peer review. However, these studies were still considered to contain reliable information because they were all produced by reputable research institutes. The prevalence of French and Italian studies simply reflects the importance of coppice forest in these countries: coppice forests cover over 6 million ha in France and over 3 million ha in Italy, representing a crucial forest management approach.

The large amount of data points assembled in the master data base provides a solid platform, from which meaningful information can be extracted. Of course, the studies constituting this database are extremely variable in their scope, goals, and methodologies. Even if methodological harmonization was achieved (Koŝir et al. 2015), these studies would still reflect the different species and different silvicultural practices typical of each country, providing an unbalanced dataset as a result of unbalanced country contributions. For this reason, our analyses can clearly detect the main trends but cannot go deeply into the specific details. In general, meta-analyses trade accuracy for robustness, which is their main asset (Borenstein et al. 2009). 
Fig. 3 Forwarding productivity as a function of maximum extraction distance and load size

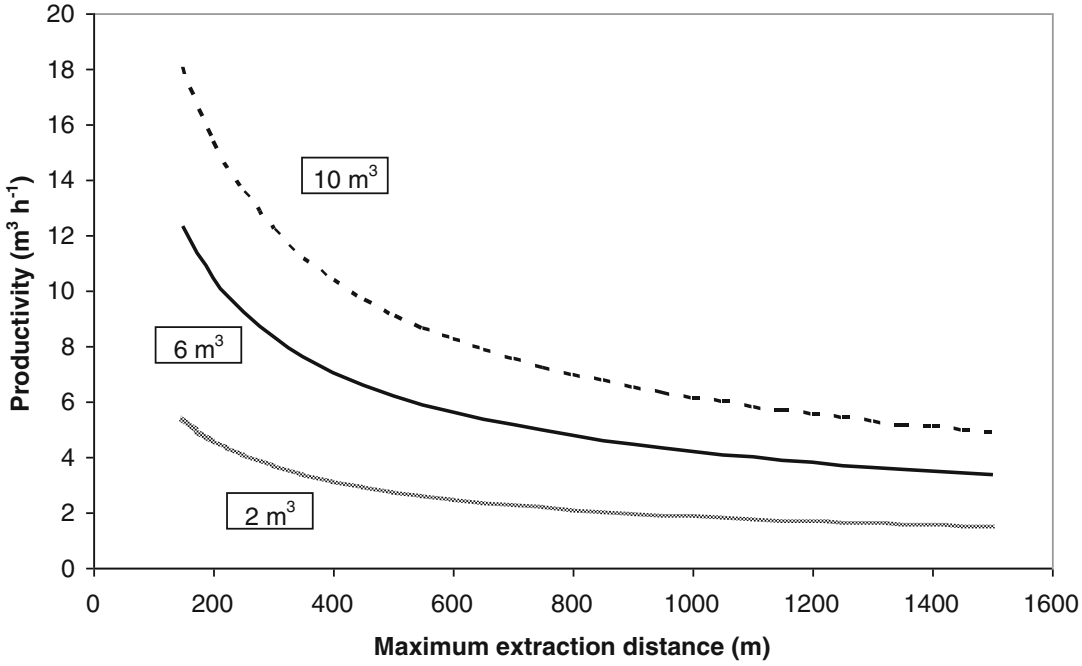

In that regard, it is important to stress that the data points used for the analysis are not the equivalent of single studies, and that a single study often produces more data points. This is

Table 6 Results for skidding, forwarding, and yarding by study date

\begin{tabular}{|c|c|c|c|}
\hline Study date & Up to 2005 & After 2005 & $P$ value \\
\hline \multicolumn{4}{|l|}{ Skidding } \\
\hline Data points $(n)$ & 28 & 24 & \\
\hline Productivity $\left(\mathrm{m}^{3} \mathrm{~h}^{-1}\right)$ & 1.973 & 3.962 & $<0.0001$ \\
\hline Utilization $(\%)$ & 81 & 76 & 0.1119 \\
\hline Distance $(\mathrm{m})$ & 355 & 226 & 0.1193 \\
\hline Load per turn $\left(\mathrm{m}^{3}\right)$ & 0.806 & 0.891 & 0.3532 \\
\hline Total removal $\left(\mathrm{m}^{3} \mathrm{ha}^{-1}\right)$ & 84 & 135 & 0.0021 \\
\hline Slope gradient (\%) & 25 & 35 & 0.0277 \\
\hline \multicolumn{4}{|l|}{ Forwarding } \\
\hline Data points $(n)$ & 14 & 27 & \\
\hline Productivity $\left(\mathrm{m}^{3} \mathrm{~h}^{-1}\right)$ & 3.112 & 7.535 & 0.0003 \\
\hline Utilization (\%) & 81 & 85 & 0.3033 \\
\hline Distance $(\mathrm{m})$ & 871 & 699 & 0.2111 \\
\hline Load per turn $\left(\mathrm{m}^{3)}\right.$ & 2.916 & 6.413 & 0.0005 \\
\hline Total removal $\left(\mathrm{m}^{3} \mathrm{ha}^{-1}\right)$ & 107 & 85 & 0.0989 \\
\hline Slope gradient $(\%)$ & 22 & 22 & 0.4657 \\
\hline \multicolumn{4}{|l|}{ Yarding } \\
\hline Data points $(n)$ & 10 & 23 & \\
\hline Productivity $\left(\mathrm{m}^{3} \mathrm{~h}^{-1}\right)$ & 2.636 & 3.366 & 0.3675 \\
\hline Utilization $(\%)$ & 81 & 74 & 0.2082 \\
\hline Distance (m) & 141 & 278 & 0.0107 \\
\hline Load per turn $\left(\mathrm{m}^{3}\right)$ & 0.314 & 0.584 & 0.0061 \\
\hline Total removal $\left(\mathrm{m}^{3} \mathrm{ha}^{-1}\right)$ & 100 & 127 & 0.1627 \\
\hline Slope gradient $(\%)$ & 59 & 56 & 0.7183 \\
\hline
\end{tabular}

$P$ values for the comparison between the two date groups conducted with the Mann-Whitney non-parametric test; utilization = productive work time/worksite time; productivity figures refer to the whole extraction team and not to the single worker especially relevant when calculating frequencies and time trends. Traditional, somewhat "archaic" technologies might be found in recent papers just because they represent the control in a comparison study, and therefore, the association of recent dates to these data points does not necessarily reflect revived interest in older methods (although it does not exclude it, either).

Similarly, concentrations of studies about one specific technology may approximate — but not necessarily describe - how popular this technology is in actual practice. In fact, research often addresses emerging technologies, not mainstream ones. Therefore, any inference produced by this study about technological preference in current practice is highly conjectural. In that regard, it is important to bear in mind that most of the data points come from France, Italy, and Spain: therefore, any technology trends shown by this study may be valid for southwestern Europe but are not necessarily true for other parts of the European Union.

In general, the productivity benchmarks reported here for coppice operations are much lower than the productivity benchmarks indicated in other previous studies about operations in high forests (cf. Eriksson and Lindroos 2014, Spinelli et al. 2015). There is a two-way causal relationship between the low productivity achieved in coppice operations and the low level of mechanization deployed there. On one hand, the low level of mechanization is one of the reasons for the limited productivity achieved in coppice operations. On the other hand, coppice stands present objective constraints (small tree size, irregular tree distribution, poor tree form, etc.) that may prevent the productivity achieved in high forests from being reached, for any given level of mechanization. This discourages the introduction of more efficient and expensive machines, and the current general trend toward larger, more sophisticated and more expensive machines is not going to make things easier (Nordfjell et al. 2010). There is a need for lighter, simpler, and cheaper versions of the same modern machines 
>used in high forests, but most machine manufacturers prefer targeting the most profitable operations, where the big money is. The development of a modern mechanization for coppice harvesting is still a niche market that is bound to attract smaller players, but its future expected growth may make it an increasingly interesting niche (Ferrari et al. 2012).

\subsection{Felling, processing, and harvesting}

With regard to felling, processing, and harvesting, the study highlights several strong trends. Mechanization boosts operator productivity, increases utilization, and reduces crew size, all of which represent vital solutions to the shortage of manual labor (Cacot et al. 2015b, Spinelli and Magagnotti 2011). Equally obvious is the indication that direct access of felling and harvesting machines to the forest is favored by flat terrain, with a mean slope gradient not higher than $10 \%$ (of course, this may include short drops and inclines with a much higher gradient). All of this is already known. However, this study also contributes new and important knowledge. First of all, it offers the evidence that mechanized felling, processing, and harvesting are viable options for coppice stands. This is quite important, considering that the viability of mechanized felling, processing, and harvesting in coppice stands is still the object of much debate (Ramantswana et al. 2012). The study also shows that different work procedures are sensitive to different factors. Regardless of technology level, processing and harvesting are most affected by stem size, because they are single-stem operations. In contrast, the effect of stem size on felling is secondary, because of the possibility of cutting more stems at a time to compensate for small stem size (Erber et al. 2016). This occurs with manual felling as well as with mechanized felling, which is generally based on multiple-stem technology and may be partly facilitated by natural clumping, as stems growing close together are easier to grab in one single motion. The successful introduction of mechanized felling is largely dependent on the growing demand for biomass, which justifies whole-tree chipping (Mitchell and Gallagher 2007).

Mechanized processing and harvesting also tend to produce more and longer assortments than do manual processing and harvesting. The main technical reason is that short logs $(1 \mathrm{~m})$ are difficult to handle with any machine, whereas long logs are too heavy for manual handling. The economic consequence is that introducing mechanization may favor an increased diversification of coppice products, possibly to the benefit of larger and more valuable structural products.

In any case, assortment type and specifications depend on tree species. This study shows a clear association between certain species and the technology level applied to felling, processing, and harvesting. However, such choice is not necessarily motivated by inherent technical requirements, but it often depends on contingent economic factors. The prevalence of chestnut in mechanized processing and harvesting studies may partly depend on inherent technical factors (i.e., the generally good form of chestnut sprouts), but it is also explained by the fact that chestnut coppice is often concentrated in specific regions, where wide availability of this raw material has fostered a whole industrial sector with the means and the perspectives for introducing mechanization (Pettenella 2001). In contrast, oak coppice is often scattered in rural areas with little industrial development, which may explain the delayed reaction to new technology opportunities (Fraser 1982).

\subsection{Extraction}

While felling, processing, and harvesting are either performed with a chainsaw or with a boom-mounted hydraulic attachment, extraction is performed with a large variety of techniques, each deployed according to different technology levels. The study shows the enduring prevalence of three systems: skidding, forwarding, and yarding. Over time, skidding seems to be losing favor, whereas forwarding and yarding are gaining popularity. This is further demonstrated by the different levels of technical progress within the systems themselves. All systems became more productive with time, but productivity increases seem to be associated with technology advances in the cases of forwarding and yarding, not skidding.

Forwarding seems particularly promising, because it requires the lowest labor input and it achieves the highest productivity, despite deployment on significantly longer extraction distances. In that regard, it is important to recall that the distance considered in the study is the maximum extraction distance, not the mean distance as used in many other similar studies. The decision to use maximum distance instead of mean distance was dictated by the fact that most papers in the database did report the maximum extraction distance, while only some of them also offered information about the mean extraction distance. Clarity about this point is especially relevant to using the models shown in Table 5 and graphed in Fig. 3. If all trips were conducted exactly from the distance reported on the $\mathrm{X}$-axis of Fig. 3 (that is, if that distance was the mean distance and not the maximum one), then actual productivity would be much lower than predicted. In fact, the productivity indicated on the Y-axis of Fig. 3 represents the mean productivity for an extraction operation conducted over a whole range of distances up to the maximum distance indicated on the X-axis; therefore, the corresponding mean extraction distance is much shorter.

Forwarding is also much less dependent on removal intensity, which makes it the choice extraction system for conversion cuts (i.e., thinning). Unfortunately, conversion to high forest is often applied to steep sites that are inaccessible to ground-based equipment (Ciancio et al. 2006). In that case, it may be worth considering conversion along corridors (Tulbure and Duduman 2012), which may offer better conditions for cost-effective cable yarding. 
Finally, the close association between terrain characteristics and extraction system demonstrates that system selection is dictated by access conditions. This may also explain the association between extraction system and tree species, because tree species often reflects terrain conditions. Yarding occurs more often with beech, because beech forests occupy higher and steeper sites than do other forest types. Similarly, mechanized ground-based extraction is more often associated with oak stands, which generally grow on rolling hills, accessible to tractors.

\section{Conclusions}

The study offers valuable benchmark figures about coppice harvesting performance. These may help direct decision-makers when trying to modernize coppice management and increase its competitive capacity, which is crucial to the survival of coppicing as an economical practice. The productivity models presented in this study indicate the crucial role of removal intensity on harvesting performance and should be considered carefully when deciding about the future of coppice management. While these models do not discriminate against conversion per se, they warn against excessively light removals, which may occur in the repeated thinning operations often applied to achieve conversion to high forest. The study also demonstrates that coppice harvesting technology has been evolving, like for all other forestry sectors. Coppice can be felled and processed mechanically, and the trend toward increasingly larger machines is clearly visible in coppice operations, as it is in high forests and plantation operations (Nordfjell et al. 2010). However, while trends are the same, the type of mechanization deployed in coppice operation is quite specific and it is generally lighter and less specialized than that used in high forests. Relatively cheap and versatile general-purpose machines (excavators, farm tractors, and light forwarders) still represent the backbone of coppice mechanization, which is consistent with the rural and small-scale character of the coppice economy.

Acknowledgments The study was supported by COST Action FP1301 "Eurocoppice", as part of the activities conducted within the scope of WG3 "Utilization and products". The authors would like to thank Mariusz Bembenek and Philippe Ruch for their support with the data collection and analysis.

Funding COST Action FP1301 "Eurocoppice" provided funding for the travel expenses necessary for the author panel meetings.

\section{Appendix}

List of studies used for the meta-analysis

\begin{tabular}{clllll}
\hline Compiler & Reference & Country & Year & Published & English \\
Emmanuel & $\begin{array}{c}\text { Project } n^{\circ} \text { SD03, date : 1996, } \\
\text { Cacot }\end{array}$ & France & 1996 & 0 & 0
\end{tabular}

\begin{tabular}{|c|c|c|c|c|}
\hline $\begin{array}{c}\text { Emmanuel } \\
\text { Cacot }\end{array}$ & $\begin{array}{l}\text { Project nºSD03, date : } 1997 \text {, } \\
\text { location :Chalvignac }\end{array}$ & France & 1996 & 0 \\
\hline $\begin{array}{l}\text { Emmanuel } \\
\text { Cacot }\end{array}$ & $\begin{array}{l}\text { Project n }{ }^{\circ} \text { SD03, date : 1996, } \\
\text { location :Saint Alvère (24) }\end{array}$ & France & 1996 & 0 \\
\hline $\begin{array}{l}\text { Raffaele } \\
\quad \text { Spinelli }\end{array}$ & $\begin{array}{l}\text { Grulois S., Cassotti P., Julien } \\
\text { C., Perinot C. (1996) } \\
\text { Productivity of harvesting } \\
\text { operations in coppice forests } \\
\text { in the Mediterranean } \\
\text { region:situation in France. } \\
\text { Annali Istituto Sperimentale } \\
\text { di Selvicoltura 27: 183-190 }\end{array}$ & France & 1996 & 1 \\
\hline $\begin{array}{c}\text { Emmanuel } \\
\text { Cacot }\end{array}$ & $\begin{array}{l}\text { Project nº }{ }^{\circ} \text { D03, date : } 1998, \\
\text { location : La Gane (19) }\end{array}$ & France & 1997 & 0 \\
\hline $\begin{array}{c}\text { Emmanuel } \\
\text { Cacot }\end{array}$ & $\begin{array}{l}\text { Project nºSD03, date : } 1997 \text {, } \\
\text { location : Les Piles (24) }\end{array}$ & France & 1997 & 0 \\
\hline $\begin{array}{l}\text { Emmanuel } \\
\text { Cacot }\end{array}$ & $\begin{array}{l}\text { Project nºSD03, date : } 1997, \\
\text { location : Le Rouget (15) }\end{array}$ & France & 1997 & 0 \\
\hline $\begin{array}{c}\text { Emmanuel } \\
\text { Cacot }\end{array}$ & Project nºD03, date : 1997 & France & 1997 & 0 \\
\hline $\begin{array}{c}\text { Emmanuel } \\
\text { Cacot }\end{array}$ & $\begin{array}{l}\text { Project nº SD03, date : 1997, } \\
\text { location : Palat }\end{array}$ & France & 1998 & 0 \\
\hline $\begin{array}{c}\text { Emmanuel } \\
\text { Cacot }\end{array}$ & $\begin{array}{l}\text { Project n'SD03, date : } 1998, \\
\text { location : La Pouge (19) }\end{array}$ & France & 1998 & 0 \\
\hline $\begin{array}{c}\text { Emmanuel } \\
\text { Cacot }\end{array}$ & $\begin{array}{l}\text { Project nºD03, date : } 1998, \\
\text { location : Puy d'Arnac (19) }\end{array}$ & France & 1998 & 0 \\
\hline $\begin{array}{l}\text { Emmanuel } \\
\text { Cacot }\end{array}$ & $\begin{array}{l}\text { Project nºSD03, date : } 1998, \\
\text { location : Saligoux (15) }\end{array}$ & France & 1998 & 0 \\
\hline $\begin{array}{c}\text { Emmanuel } \\
\text { Cacot }\end{array}$ & $\begin{array}{l}\text { Project nºD03, date : } 1998, \\
\text { location : Saint Crépin (24) }\end{array}$ & France & 1998 & 0 \\
\hline $\begin{array}{c}\text { Emmanuel } \\
\text { Cacot }\end{array}$ & $\begin{array}{l}\text { Project nº SD04, date : 01-05/ } \\
\text { 02/1999, location : Noërs } \\
\text { (54) }\end{array}$ & France & 1999 & 0 \\
\hline Emmanuel & Project n ${ }^{\circ} \mathrm{SD} 06$, date $: 25 / 01 /$ & France & 2000 & 0 \\
\hline
\end{tabular}

Cacot 2000, location : Rougnac I

(16)

Emmanuel Project n ${ }^{\circ} \mathrm{SY} 54$, date : 05/12/ France $2000 \quad 0 \quad 0$

Cacot 2000, location : Ambazac I

(87)

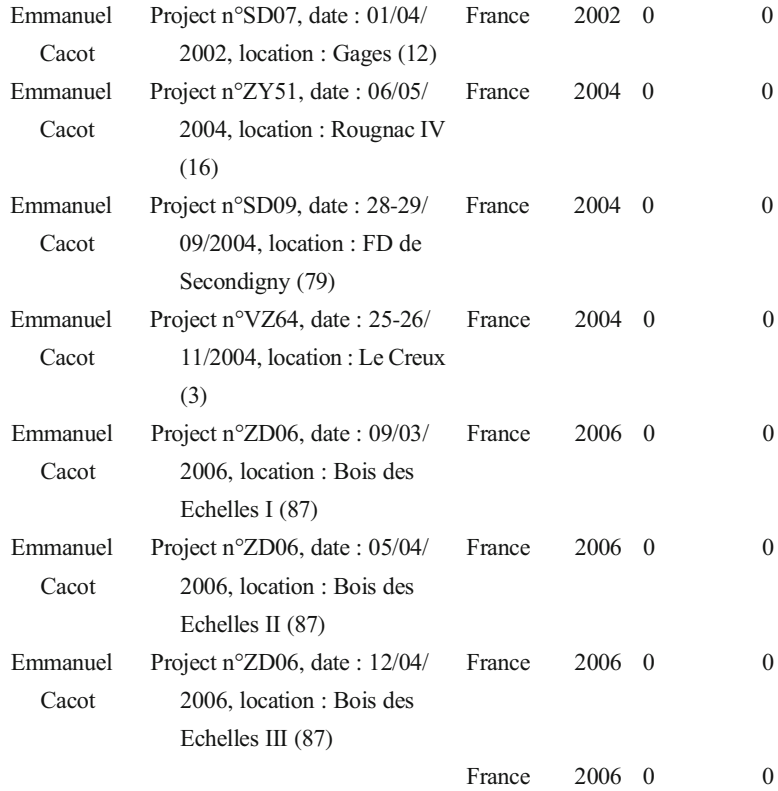

1

(1)

0

0

0

0

0

0

0

0

0

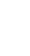

0

0

0

0

0

0

0

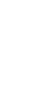


Emmanuel Project n' ${ }^{\circ}$ DD1, date : 01/06/

Cacot 2006, location : Lacabarède (81)

Emmanuel Project n ${ }^{\circ}$ SD11, date : 01/07/

Cacot 2006, location : Caraman

(31)

Emmanuel

Project ${ }^{\circ}$ SD11, date : 01/09/

Cacot

2006, location : Labastide-

Rouairoux (81)

Emmanuel Project $n^{\circ}$ SD11, date : 16-17

Cacot 11/06, location : Dompierre-

sur-Nièvre (58)

Emmanuel Project $n^{\circ}$ SD10, date : 16/10- France $2006 \quad 0 \quad 0$

Cacot 15/11/06, location : Sussac

(87)

Emmanuel Project $n^{\circ}$ SD10, date : 16/11- France $2006 \quad 0$

Cacot 20/12/06, location : Cognac-

la-Forêt (87)

Emmanuel Project $n^{\circ}$ SD12, date : 04-05/

Cacot 12/07, location : Savignac-

de-Miremont (24)

Emmanuel

Caco

Project n ${ }^{\circ}$ SD12, date : $18 / 12$

2007, location : St Outrille

(18)

Emmanuel Project $n^{\circ} \mathrm{SD} 12$, date $: 22 / 01 / \quad$ France $2008 \quad 0$

Cacot 2008, location : FD de

Bommiers III (36)

Emmanuel Project ${ }^{\circ} \mathrm{B} 00160$, date : 20-21/ France 200800

Cacot 10/2008, location : FD de la

Mothe-clédou II (16)

Emmanuel Project $\mathrm{n}^{\circ} \mathrm{B} 00609$, date : 25/07/ France 201100

Cacot 2011, location : Combiers

(16)

Cacot 2011, location : Rougnac

(16)

Emmanuel Project $n^{\circ}$ B00609, date : 21/02/ France 201100

Cacot 2011, location : Chapelle

Péchaud (24)

Emmanuel Project $\mathrm{n}^{\circ} \mathrm{B} 00609$, date : 19/01/ France 201100

Cacot 2015, location : Villandraut

(33)

Emmanuel Project $n^{\circ}$ B00609, date : 21/01/ France 201500

Cacot 2015, location : Noaillan

Route du Reche (33)

Emmanuel Project ${ }^{\circ}$ B00609, date:04/02/ France 201500

Cacot 2015, location : Vaurez (24)

Emmanuel Project $n^{\circ}$ SD03, date: 1996, France $2015 \quad 0 \quad 0$

Cacot location : Le Bugue (24)

Zbigniew Suchomel C., Becker G., Pyttel Germany $2011 \quad 1 \quad 1$

Karasze- P. (2011). Fully Mechanized

wski Harvesting in Aged Oak

Coppice Stands. Forest

Products Journal 61 (4):

290-296

$\begin{array}{ccccc}\text { Raffaele } & \text { Baldini S. (1973) Relazione Italy } & 1973 & 1 & 0 \\ \text { Spinelli } & \text { sulla utilizzazione } \\ & \text { sperimentale di bosco ceduo } \\ & \text { nella FD di Cecina. } \\ & \text { Cellulosa e Carta 6: } 37-51 .\end{array}$

Piegai F., Uzielli L.,

Hippoliti G. (1980)

Raffaele Diradamento geometrico a $\quad$ Italy $\quad \begin{array}{llll}1980 & 1 & 0\end{array}$

Spinelli strisce in un ceduo di cerro:

prove comparative fra sei

sietmi di lavoro con vari

mezzi di esbosco. Cellulosa

e carta $31: 3-23$

Raffaele Currò P., Verani S. (1984) Italy $\quad 1984 \quad 1 \quad 0$

Spinelli Tempi di lavoro e

rendimenti di esbosco in un

ceduo di cerro con

Timberjack 225. CSAF

Quaderni di Ricerca ${ }^{\circ}{ }^{4} .6$

p.

Raffaele Currò P., Verani S. (1986) Italy $1986 \quad 1 \quad 0$

Spinelli Prove di Concentramento

del legname in ceduo di

cerro con due tipi di gru a

cavo. CSAF Quaderni di

Ricerca ${ }^{\circ} 10.11 \mathrm{p}$.

Raffaele Baldini S., Garavaglia S.

Spinelli (1987). The farm tractor for

hauling operations.

Proceedings of the FAO/

ECE/ILO seminar on small-

scale logging operations and

machines.Garpenberg 15-18

June, 1987. 8 p.

Raffaele

Baldini S. (1987) Prove di

Italy

$1987 \quad 1$

0

nelle conversioni. In:

AA.VV: (1987) La

conversione dei boschi

cedui in alto fusto: stato

attuale delle ricerche. UNIF,

Viterbo. 84 p.

Raffaele

Macchine e sistemi di lavoro

tradizionali nella

utilizzazione dei castagneti

trattati a ceduo matricinato.

Monti e Boschi 39: 11-18

Raffaele Baldini S., Spinelli R. (1989)

Raffa

Raffaele Spinelli R., Baldini S. (1992)

quercino in stazione

pianeggiante. Cellulosa e

Carta 43: 33-41
Spinelli Utilizzazione di un bosco

ceduo matricinato con

esbosco effettuato da

animali. Monti e Boschi 2/

89: 39-43

Spinelli

AA.VV. (1990) Orientamenti

operativi per la

valorizzazione dei cedui

marginali. Ministero

dell'Agricoltura e Foreste.

Roma. 285 p.

Utilizzazione di un ceduo

$\begin{array}{llll} & 1989 & 1 & 0\end{array}$

$1990 \quad 1$

0

Spinelli

Italy

19921

0 


\begin{tabular}{|c|c|c|c|c|}
\hline $\begin{array}{l}\text { Raffaele } \\
\quad \text { Spinelli }\end{array}$ & $\begin{array}{l}\text { Baldini S. (1992) Prove di } \\
\text { idoneità all'impiego } \\
\text { forestale del trattore Goldoni } \\
\text { Forestal. CNR Internal } \\
\text { Report. } 114 \mathrm{p} .\end{array}$ & Italy & 1992 & 0 \\
\hline $\begin{array}{l}\text { Raffaele } \\
\quad \text { Spinelli }\end{array}$ & $\begin{array}{l}\text { Baldini S., Spinelli R. (1994) } \\
\text { Prove di utilizzazione dei } \\
\text { cedui di faggio } \\
\text { sull'Appennino Tosco- } \\
\text { Emiliano. CNR Internal } \\
\text { Report. } 18 \text { p. Baldini S., } \\
\text { Brunetti M., Spinelli R. } \\
\text { (1995) Innovative } \\
\text { harvesting techniques in the } \\
\text { Italian }\end{array}$ & Italy & 1994 & 0 \\
\hline $\begin{array}{l}\text { Raffaele } \\
\text { Spinelli }\end{array}$ & $\begin{array}{l}\text { Quercus cerris coppice stands. } \\
\text { Project AIR } 2 \text { CT94-0905 } \\
\text { MEDCOP. Consolidated } \\
\text { Progress Report 1st year. EC } \\
\text { DGXII Brussels, Belgium. }\end{array}$ & Italy & 1995 & 0 \\
\hline $\begin{array}{l}\text { Raffaele } \\
\quad \text { Spinelli }\end{array}$ & $\begin{array}{l}\text { Cantiani P., Spinelli R. (1996) } \\
\text { Conversion to high forest of } \\
\text { Turkey oak coppices: } \\
\text { technical and economical } \\
\text { assessment of the first } \\
\text { conversion stage. Annali } \\
\text { Istituto Sperimentale } \\
\text { Selvicoltura - Arezzo 27: } \\
\text { 191-199 }\end{array}$ & Italy & 1996 & 1 \\
\hline $\begin{array}{l}\text { Raffaele } \\
\quad \text { Spinelli }\end{array}$ & $\begin{array}{l}\text { Spinelli R., Caliari M., Baldini } \\
\text { S., Fabbri P.G. (1996) } \\
\text { Harvesting holm-oak } \\
\text { coppice conversions in } \\
\text { Southern Italy: results from } \\
\text { the six comparative trials } \\
\text { held in Staiti (RC). Project } \\
\text { AIR } 2 \text { CT94-0905 } \\
\text { MEDCOP. Consolidated } \\
\text { Progress Report 2nd year. } \\
\text { EC DGXII Brussels, } \\
\text { Belgium. }\end{array}$ & Italy & 1996 & 0 \\
\hline $\begin{array}{l}\text { Raffaele } \\
\quad \text { Spinelli }\end{array}$ & $\begin{array}{l}\text { Spinelli R., Ricci F., Spinelli R. } \\
\text { (1998) Prove in campo con } \\
\text { una macchina abbattitrice: il } \\
\text { feller-buncher Elmek } \\
\text { EnHar. Sherwood - Foreste e } \\
\text { Alberi Oggi 38: 41-45 }\end{array}$ & Italy & 1998 & 1 \\
\hline $\begin{array}{l}\text { Raffaele } \\
\text { Spinelli }\end{array}$ & $\begin{array}{l}\text { Spinelli R., Ricci F., Spinelli R. } \\
\text { (1998) Esbosco a strascico } \\
\text { con mini-trattore articolato. } \\
\text { Legno Cellulosa e Carta 4: } \\
\text { 26-31 }\end{array}$ & Italy & 1998 & 1 \\
\hline $\begin{array}{l}\text { Raffaele } \\
\text { Spinelli }\end{array}$ & $\begin{array}{l}\text { Spinelli R., Spinelli R. (2000). } \\
\text { L'allestimento meccanizzato } \\
\text { del ceduo di castagno. Monti } \\
\text { e Boschi } 51 \text { (1): 36-42 }\end{array}$ & Italy & 2000 & 1 \\
\hline $\begin{array}{l}\text { Raffaele } \\
\quad \text { Spinelli }\end{array}$ & $\begin{array}{l}\text { Verani S., Sperandio G. (2003) } \\
\text { Tre mezzi per l'esbosco di } \\
\text { legna da ardere. Sherwood - }\end{array}$ & Italy & 2003 & 1 \\
\hline
\end{tabular}

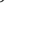

Raffaele
Spinelli
Raffaele

Foreste e Alberi Oggi 92:

13-19

Spinelli R., Nati C., Magagnotti Italy $\quad \begin{array}{llll}2005 & 1 & 0\end{array}$

N. (2005) Biomassa dalla

manutenzione delle bande

boscate polivalenti. Terra e

Vita 12: 82-88.

Fabiano F. (2006)

Italy $2006 \quad 1 \quad 0$

Movimentazione manuale

della legna da ardere -

Entità, rischi e sicurezza

nell'esbosco "a soma" con

trattore. Sherwood - Foreste

e Alberi Oggi 120: 33-37

Raffaele Spinelli R., Nati C., Magagnotti Italy $2006 \quad 0 \quad 0$

Spinelli N., Verani S. (2006)

Raccolta integrata di legna

da ardere e cippato dalla

gestione dei cedui quercini

degradati in Molise. CNR

Internal Report. 12p

Raffaele

AA.VV. (2006) Guidelines for

the development of a forest

chips supply chain. GAL

Prealpi e Dolomiti, Sedico,

BL - Italy.

Raffaele $\quad$ Bresciani A., Fratini R., $\quad$ Italy $\quad 2007 \quad 1 \quad 0$

Spinelli Lorenzoni M., Piegai F.

(2007) Tempi e costi nelle

utilizzazioni boschive.

Sherwood - Foreste e Alberi

Oggi 130: 5-11

Raffaele Piegai F. (2005) Tagli di

$2007 \quad 1$

0

utilizzazione e di

avviamento nei cedui

quercini. Sherwood -Foreste

e Alberi Oggi 117: 5-8

Raffaele

Spinelli R., Cuchet E., Roux P.

(2007) Biomass \&

Bioenergy 31: 205-210

Raffaele Spinelli R., Magagnotti N.

Spinelli (2007) Protezione idraulica,

ambiente e biomassa: un

approccio integrato alla

manutenzione degli alvei

fluviali. Alberi e territorio

Raffaele Spinelli R., Magagnotti N.

(2007) Biomassa dai boschi

di neoformazione: casi di

studio in Friuli-Venezia

Giulia. Sherwood - Foreste e

Alberi Oggi 135: 45-49.

Raffaele Moscatelli M, Pettenella D,

Spinelli

Spinelli R, (2007).

Produttività e costi della

lavorazione meccanizzata

dei cedui di castagno in

ambiente appenninico.

Forest@ 4 (1): 51-62 


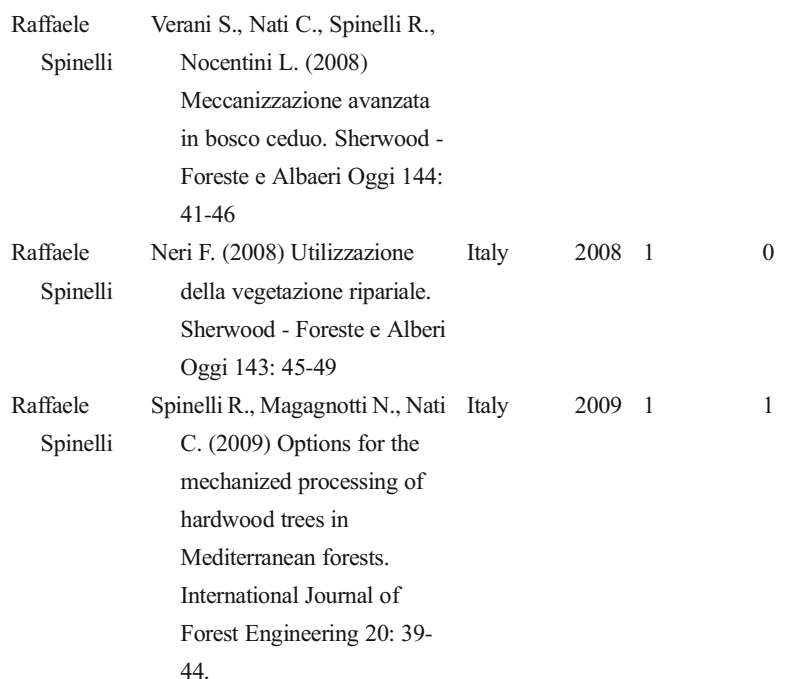

Raffaele Picchio R., Maesano M.,

Spinelli Savelli S., Marchi E. (2009)

Productivity and energy

balance in conversion of a

Quercus cerris L. coppice

stand into high forest in

Central Italy. Croatian

Journal of Forest

Engineering 30: 15-26

Spinelli Cable logging opportunities

for firewood in Calabrian

forests -Biosystems

Engineering 102: 63-68

Enelli R., Magagnoti N.,

Spinelli Lombardini C. (2010)

Performance, capability and

costs of small-scale cable

yarding technology. Small-

scale Forestry 9: 123-135

Raffaele Magagnotti N., Spinelli R.

Spinelli (2011) Integrating animal

and mechanical operations

in protected areas. Croatian

Journal of Forest

Engineering 32: 489-499

\begin{tabular}{|c|c|c|c|c|}
\hline $\begin{array}{l}\text { Raffaele } \\
\quad \text { Spinelli }\end{array}$ & $\begin{array}{l}\text { Spinelli R., Magagnotti N. } \\
\text { (2011) Prove di esbosco } \\
\text { nell'Appennino Tosco- } \\
\text { Emiliano. CNR Internal } \\
\text { Report. } 12 \text { p. }\end{array}$ & Italy & 2011 & 0 \\
\hline $\begin{array}{l}\text { Raffaele } \\
\quad \text { Spinelli }\end{array}$ & $\begin{array}{l}\text { Magagnotti N., Pari L., Spinelli } \\
\text { R. (2012) Re-engineering } \\
\text { firewood extraction in } \\
\text { traditional Mediterranean } \\
\text { coppice stands. Ecological } \\
\text { Engineering 38: } 45-50\end{array}$ & Italy & 2012 & 1 \\
\hline $\begin{array}{l}\text { Raffaele } \\
\quad \text { Spinelli }\end{array}$ & $\begin{array}{l}\text { Suchomel C., Spinelli R., } \\
\text { Magagnotti N. (2012) } \\
\text { Productivity of processing } \\
\text { hardwoods from coppice } \\
\text { forests. Croatian Journal of }\end{array}$ & Italy & 2012 & 1 \\
\hline
\end{tabular}

Italy $\quad \begin{array}{lll}2011 & 1 & 1\end{array}$
Forest Engineering 33: 39-

47

Raffaele Spinelli

Spinelli R., Magagnotti N.

Italy

20121

1

(2012) Wood extraction

with farm tractor and sulky:

estimating productivity, cost

and energy consumption.

Small-scale Forestry 11: 73-

85

Raffaele AA.VV. (2012) Linee guida per Italy $2012 \quad 1 \quad 0$

Spinelli la gestione della vegetazione

di sponda dei corsi d'acqua

secondo criteri di

sostenibilità ecologica ed

economica. Regione

Toscana - Giunta Regionale.

$106 \mathrm{p}$.

$\begin{array}{llllll}\text { Raffaele } & \text { Magagnotti N., Spinelli R. } & \text { Italy } & 2012 & 1 & 1\end{array}$

Spinelli (2012) Replacing steel cable

with synthetic rope to reduce

operator workload in log

winching operations. Small-

scale Forestry 11: 223-236

Raffaele

Spinelli

Spinelli R., Ebone A., Gianella Italy

M. (2014) Biomass

production from traditional

coppice management in

northern Italy. Biomass and

Bioenergy 62: 68-73.

Raffaele

Spinelli

Schweier J., Spinelli R.,

Italy $2015 \quad 1$

Magagnotti N., Becker G.

(2015) Mechanized coppice

harvesting with new small-

scale feller-bunchers: results

from harvesting trials with

newly manufactured felling

heads in Italy. Biomass \&

Bioenergy 72: 85-94

Raffaele

Spinelli

Spinelli R., Lombardini C.,

Magagnotti N., De

Francesco F., Aminti G.

(2015) Rapporto sui cantieri

PIT - Provincia di Como.

CNR Internal Report. $18 \mathrm{p}$.

Raffaele
Spinelli

Magagnotti N., Ottaviani-

Aalmo G., Brown M.,

Spinelli R. (2015) A new

device for reducing crew

size and operator workload

during log winching

operations. Manuscript

submitted to Biosystems

Engineering

Mariusz

Mederski P. et al. (2013-2016)

Bemben-

Research project No. EO-

ek 5011-179/12 supported by

the General Directorate of

State Forests in Warsaw

Matevž

Rakič, M.,1988, Problematika

Mihelič

iskorištavanja šuma u Š.I.K.
Italy $\quad 2015 \quad 1 \quad 1$

0

0
Poland $2014 \quad 0 \quad 0$ 


\begin{tabular}{|c|c|c|c|c|c|c|c|c|c|c|c|}
\hline & "Crvena zastava" Kruševac & & & & & Eduardo & Tolosana E y Martín M: & & & & \\
\hline & sa posebnim osvrtom za & & & & & Tolosana & Informe final "Estudio de & & & & \\
\hline & dvofazno privlačenje, & & & & & & rendimientos entre & & & & \\
\hline & University of Belgrade, & & & & & & operaciones manuales y & & & & \\
\hline & Faculty of Forestry, & & & & & & mecanizadas en la clara del & & & & \\
\hline & Bachelor Thesis, $36 \mathrm{p}$. & & & & & & rebollar de Q.Pyrenaica en & & & & \\
\hline \multirow{7}{*}{$\begin{array}{l}\text { Matevž } \\
\text { Mihelič }\end{array}$} & Bajič, V., Danilović, M., & Serbia & 2004 & 1 & 0 & & santa Colomba de Somoza & & & & \\
\hline & Mehanizirano privlačenje & & & & & & (León)”. Unpublished. 2009 & & & & \\
\hline & prorednog materiala & & & & & Eduardo & Tolosana E. Manual Técnico & Spain & 2009 & 1 & 0 \\
\hline & izdanačkim sastojinama & & & & & Tolosana & para el aprovechamiento y & & & & \\
\hline & bukve, 2004. Šumarstvo & & & & & & elaboración de biomasa & & & & \\
\hline & (Jul-Sept, 2004), number 3 , & & & & & & forestal. Ed. mundiPrensa - & & & & \\
\hline & $139-148$ & & & & & & FUCOVASA. Pag. 287-309. & & & & \\
\hline \multirow{7}{*}{$\begin{array}{l}\text { Matevž } \\
\text { Mihelič }\end{array}$} & Bajić, V.,Danilović, M., 2004, & Serbia & 2004 & 1 & 0 & & 2009 & & & & \\
\hline & Optimizacija tehnologije & & & & & Eduardo & Canga E, Fanjul A, Sánchez- & Spain & 2014 & 1 & 1 \\
\hline & prorednih seča i izdaničkim & & & & & Tolosana & García S, Alonso-Graña M, & & & & \\
\hline & sestojinama bukve na & & & & & & Majada J, 2014: & & & & \\
\hline & področju crnog vrha, & & & & & & Replacement of steel cable & & & & \\
\hline & Glasnik šumarskog fakulteta & & & & & & with synthetic rope in & & & & \\
\hline & , vol 89, 41-51 & & & & & & mountain logging & & & & \\
\hline \multirow{9}{*}{$\begin{array}{l}\text { Matevž } \\
\quad \text { Mihelič }\end{array}$} & Simončič P, Eler K, Kobal M, & Slovenia & 2014 & 1 & 0 & & operations in Castanea & & & & \\
\hline & Triplat M, Sinjur I, Žlindra & & & & & & sativa Mill. coppice stands. & & & & \\
\hline & D, Mihelič, M., Robek, R., & & & & & & Forest Systems 23(3): 461- & & & & \\
\hline & Piškur, M., Klun, J., Premrl, & & & & & & 469. & & & & \\
\hline & T., Krajnc, N. Možnosti in & & & & & Eduardo & Forestry Commission's Forest & UK & 1996 & 1 & 1 \\
\hline & omejitve pridobivanja & & & & & Tolosana & Research Technical & & & & \\
\hline & biomase iz gozdov : & & & & & & Development Branch, & & & & \\
\hline & zaključno poročilo projekta & & & & & & 1996:"Harvesting and & & & & \\
\hline & (V2-1126). & & & & & & comminution of sweet & & & & \\
\hline \multirow{8}{*}{$\begin{array}{l}\text { Eduardo } \\
\text { Tolosana }\end{array}$} & Ljubljana: Gozdarski inštitut & Spain & 2001 & 0 & 0 & & chesnut coppice for use as & & & & \\
\hline & Slovenije; 2014. Ranz, P P. & & & & & & fuel stock for electricity & & & & \\
\hline & Modelos de rendimientos y & & & & & & production". Technical Note & & & & \\
\hline & costes de las claras sobre & & & & & & 28/96, 8 pages & & & & \\
\hline & rebollares de Quercus & & & & & Eduardo & Forestry Commission's Forest & UK & 2011 & 0 & 1 \\
\hline & pyrenaica Wild. Master & & & & & Tolosana & Research Technical & & & & \\
\hline & Thesis directed by Tolosana, & & & & & & Development, 2011: & & & & \\
\hline & E (unpublished). 2001 & & & & & & "Tractor Based Mechanised & & & & \\
\hline \multirow{8}{*}{$\begin{array}{l}\text { Eduardo } \\
\text { Tolosana }\end{array}$} & Tolosana E, Ambrosio Y, & Spain & 2002 & 0 & 0 & & Harvesting in Sweet & & & & \\
\hline & Agudín S \& Boticario P: & & & & & & Chestnut Coppice". Project & & & & \\
\hline & Estudio de tiempos y & & & & & & Report Reference & & & & \\
\hline & rendimientos de la saca con & & & & & & FCPR040, 18 pages & & & & \\
\hline & cable aéreo en montes de & & & & & Eduardo & Forestry Commission's Forest & Uk & 2012 & 0 & 1 \\
\hline & Lleida y Barcelona. UPM \& & & & & & Tolosana & Research Technical & & & & \\
\hline & CPF de Catalunya & & & & & & Development, 2012: & & & & \\
\hline & (unpublished), 2002 & & & & & & "Comparison of Mechanised & & & & \\
\hline \multirow{5}{*}{$\begin{array}{l}\text { Eduardo } \\
\text { Tolosana }\end{array}$} & Rodríguez J, Ruiz D, Piqué M, & Spain & 2002 & 0 & 0 & & and Motor-manual & & & & \\
\hline & Tolosana E: Experiencia de & & & & & & Harvesting in Sweet & & & & \\
\hline & desembosc amb cable aeri. & & & & & & Chestnut Coppice". Job & & & & \\
\hline & Aprofitament d'alzina a la & & & & & & Report Reference FCJR081, & & & & \\
\hline & Selva. CPF de Catalunya. & & & & & & 23 pages & & & & \\
\hline
\end{tabular}


Cacot E, Maire L, Chakroun M, Peuch D, Montagny X, Perrinot C, Bonnemazou M (2015a) a La mécanisation du bûcheronnage dans les peuplements feuillus - Synthèse opérationnelle. Institut Téchnologique FCBA, Champs-sur-Marne, p 38

Cacot E, Grulois S, Thivolle-Cazat A, Magaud P (2015b) B mechanization of French logging operations: challenges and prospects in 2020. In: Kanzian C, Erber G, Kühmaier M (eds) Forest engineering: making a positive contribution. Abstracts and Proceedings of the 48th Symposium on Forest Mechanization, Linz, 2015. p 512

Chai T, Draxler R (2014) Root mean square error (RMSE) or mean absolute error (MAE)? - arguments against avoiding RMSE in the literature. Geosci Model Dev 7:1247-1250

Ciancio O, Corona P, Lamonaca A, Portoghesi L, Travaglini D (2006) Conversion of clearcut beech coppices into high forests with continuous cover: a case study in central Italy. For Ecol Manag 224:235-240

Erber G, Holzleitner F, Kastner M, Stampfer K (2016) Effect of multi-tree handling and tree-size on harvester performance in small-diameter hardwood thinnings. Silva Fennica $50: 17$ particle id 1428

Eriksson M, Lindroos O (2014) Productivity of harvesters and forwarders in CTL operations in northern Sweden based on large follow-up datasets. Int J For Eng 25:179-200

Ferrari E, Spinelli R, Cavallo E, Magagnotti N (2012) Attitudes towards mechanized cut-to-length technology among logging contractors in northern Italy. Scand J For Res 27:800-806

Fraser A (1982) The role of deciduous woodlands in the economy of rural communities. Int J Urb For 6:37-47

Hédl R, Kopecky M, Komàrek J (2010) Half a century of succession in a temperate Oakwood: from species-rich community to mesic forest. Divers Distrib 16:267-276

Jansen P, Kuiper L (2004) Double green energy from traditional coppice stands in the Netherlands. Biomass Bioen 26:401-402

Kirby K, Watkins C (1998) The ecological history of European forests. CAB International, Oxford, p. 373 ISBN 0-85199-256-0

Koŝir B, Magagnotti N, Spinelli R (2015) The role of work studies in forest engineering: status and perspectives. Int J For Eng 26:160-170

Magagnotti N, Pari L, Spinelli R (2012) Re-engineering firewood extraction in traditional Mediterranean coppice stands. Ecol Eng 38:45-50

McEwan A, Magagnotti N, Spinelli R (2016). The effects of number of stems per stool on cutting productivity in coppiced Eucalyptus plantations. Silva Fennica 50, article id 1448. 14 p.

Mitchell D, Gallagher T (2007) Chipping whole trees for fuel chips: a production study. Southern J Appl For 4:176-180

Nicolescu V, Barčić D, Carvalho J, Dimitriou I, Dohrenbusch A, Dubravac T, Ertekin M, Folcz A, Frank N, Hernea C, Jansen P, Löf M, Molnár D, Nordfjell T, Özel H, Rodrigues A, Trajkov P,
Şimon D, Weih M. (2014) Ecology and silvicultural management of coppice forests in Europe. Proceedings of the 1st Eurocoppice Conference, Florence. Downloaded from: www.eurocoppice.unifreiburg.de/intern/pdf/conference_1/nicolescu-ecology-andsilvicultural-management. 26 February 2014

Nordfjell T, Björheden R, Thor M, Wästerlund I (2010) Changes in technical performance, mechanical availability and prices of machines used in forest operations in Sweden from 1985 to 2010. Scand J Forest Res 25:382-389

Pettenella D (2001) Marketing perspectives and instruments for chestnut products and services. For Snow Landsc Res 76:511-517

Ramantswana M, McEwan A, Pauw J (2012) Determining the effect of tree size, bark-wood bond strength and tree form on the productivity of an excavator-based harvester in Acacia mearnsii in the KwaZuluNatal forestry region of South Africa. Southern For J For Sci 74: $151-157$

SAS Institute Inc (1999) StatView reference. SAS Publishing, Cary, p 84 93

Siry J, Cubbage F, Ahmed M (2005) Sustainable forest management: global trends and opportunities. For Pol Econ 7:551-561

Spinelli R, Magagnotti N (2011) The effects of introducing modern technology on the financial, labour and energy performance of forest operations in the Italian alps. For Pol Econ 13:520-524

Spinelli R, Magagnotti N, Lombardini C (2010) Performance, capability and costs of small-scale cable yarding technology. Small Scale For 9:123-135

Spinelli R, Ebone A, Gianella M (2014) Biomass production from traditional coppice management in northern Italy. Biomass bioenerg 62: $68-73$

Spinelli R, Magagnotti N, Visser R (2015) Productivity models for cable yarding in alpine forests. Eur J For Eng 1:9-14

Splechtna B, Gratzer G, Black B (2005) Disturbance history of a European old-growth mixed-species forest - a spatial dendroecological analysis. J Veg Sci 16:511-522

Szabò P (2009) Open woodland in Europe in the Mesolithic and in the middle ages: can there be a connection? For Ecol Manag 257:23272330

Tulbure C, Duduman G (2012) A conversion method of young hornbeam coppices and its possible impact on future stand structural attributes. Ann. For Res 55:281-296

Vacik H, Zlatanov T, Trajkov P, Dekanić S (2009) Role of coppice forests in maintaining forest biodiversity. Silva Balc 10:35-45

Wolfslehner B, Krajter S, Jovic D, Nestorovski L, Velichkov I (2009) Framing stakeholder and policy issues for coppice forestry in selected central and south-eastern European countries. Silva Balc 10:21-34 